\title{
Palestinian Perspective on Peace with Israel
}

Author: Kelly Wright

Faculty Mentor: Emile Sahliyeh, Department of Political Science and International Studies Major, College of Arts and Sciences

Department: Department of Political Science and International Studies Program, College of Arts and Sciences \& Honors College 


\section{Bio:}

Kelly Wright is graduating magna cum laude with a Bachelor of Arts degree with a major in International Studies and a minor in German. She is the recipient of a Board of Regents Chancellor's Scholarship, and has earned membership in Golden Key Honour Society. Kelly has performed as part of the Phantom Regiment Drum and Bugle Corps and the Carolina Crown Drum and Bugle Corps. As a result of her Honors thesis with Dr. Emile Sahliyeh, she is also graduating as a Distinguished Honors Scholar from the Honors College. She has been awarded the Hatton W. Sumners Scholarship and will attend graduate school at UNT to pursue a masters degree in Public Administration. 


\begin{abstract}
:
The century-long struggle between the Israelis and Palestinians has been transformed within the last 20 years. Although a trend toward peace and accommodation has emerged, another competing religious trend made compromise more difficult between the two communities. This paper explores the Palestinian perspective on peace and conflict with Israel. It examines political ideologies and Palestinian public opinion polls, as well as results of the recent elections. In the Palestinian political scene, a competitive, two-party system has emerged, dominated by Fatah and Hamas. While Palestinians support negotiations with Israel, the Hamas victory in the January 2006 elections further complicates the process. It will certainly have a major impact on the future of the Palestinian-Israeli conflict and possibly on the upcoming Israeli elections.
\end{abstract}




\section{Introduction}

Although the century-long struggle between the Israelis and Palestinians has been transformed within the last 20 years, the story and opinion of the Palestinians has continued to be overshadowed by suicide bombings and missile attacks. The Palestinians' struggle is based on the same issue as it is with the Israelis: They both fight for the "Land of Palestine," which both claim is rightfully theirs.

To better articulate the current conditions in the Palestinian/Israeli conflict, a brief summary of the more influential events is necessary. For approximately 400 years, the Ottoman Caliphate ruled over Palestine, with its reign ending after World War I. By 1922, about 88\% of its population was Arab Muslim, Christian, or Druze. ${ }^{1}$ Although Jews had begun to slowly migrate to Palestine in the late $19^{\text {th }}$ century, by 1947 the Jewish community owned only $6 \%$ to $8 \%$ of the total land and made up roughly one-third of the population. ${ }^{2}$ Despite being a statistical minority, the United Nations General Assembly voted in favor of Resolution 181, which called for the creation of two states in Palestine and gave the Jewish state $56 \%$ of the territory. ${ }^{3}$

The situation for the Palestinians further deteriorated following the 1948 Arab-Israeli War, in which Israel established itself as an independent state, capturing $77 \%$ of Palestine. Neighboring Egypt maintained control over the Gaza Strip, and Jordan claimed sovereignty over the West Bank. ${ }^{4}$ This loss, known to the Arabs as the nakba, or catastrophe, led to a massive amount of dislocation and economic deprivation among the Palestinians and left them fragmented, disillusioned, and incapable of representing themselves on the international scene. ${ }^{5}$

In 1974, following years of discontent and multiple failures to resolve the conflict through diplomatic and military means, the Arab League finally recognized the Palestine Liberation Organization (PLO), led by Yasir Arafat, as the official representative of the 
Palestinian people. This leadership was exiled to Tunisia following the Israeli invasion of Lebanon in 1982. However, several years later the Palestinians were finally able to mobilize against their Israeli occupiers in the 1987 Intifada (or uprising); coordinating strikes, demonstrations, tax resistance, and boycotts of Israeli products. ${ }^{6}$

After years of negotiations, the Declaration of Principles (DOP) was signed in 1994, which stipulated that Israel must eventually surrender to the Palestinian National Authority, dayto-day civil authority over parts of the Gaza Strip and West Bank. In addition, as part of the DOP, the Palestinians successfully held elections on January 20, 1996, in which Yasser Arafat was elected president of the Palestinian National Authority. However, to the dismay of many Palestinians, the Israelis maintained the right to build settlements and confiscate land, which ultimately led the Palestinians to once again mobilize against Israeli occupation in $2000 .^{7}$ This second Intifada, sparked by Ariel Sharon's visit to the Temple Mount, was extremely violent and resulted in the death of hundreds of people, both Israeli and Palestinian. After Israel and the United States refused to hold talks with Arafat, who was seen as a terrorist, the position of Palestinian Prime Minister was created in March 2003, and Mahmoud Abbas, also known as Abu Mazen, accepted the position.

The turbulent political situation in the Palestinian territories became even more stressed in November 2004 when Arafat died, and Abbas was subsequently elected as the Palestinian Authority president in January 2005. Since then, relations with the Israeli government have not improved, as the Gaza Strip has been completely fenced off, not only from Israel, but from Egypt as well. Moreover, Israel is building a "separation fence" along its border with the West Bank, which is negatively impacting the lives of many Palestinians. ${ }^{8}$

In order to fully explore the Palestinian perspective on the conflict, this paper will discuss 
the Palestinian public opinion, the stance of political groups, and the results of the most recent elections. First, the Palestinian public opinion is arguably the most important factor defining the Palestinian perspective on the conflict. Currently, the Palestinian people seem highly receptive to peace and negotiations with Israel, but they are not comprehensively amenable to making compromises on several key issues. Second, the Palestinian political parties can be broken down into three broad groups: Nationalists, Islamists, and Marxists. Although they all desire Palestinian independence, their varying ideologies have led them to pursue different paths, from being politically active to organizing suicide bombings. Finally, the public’s immediate need and focus on local, economic issues, and contempt for past governmental policies, was made apparent in the January elections, in which the militant Islamic party Hamas won by a wide margin. These elections will certainly change the path of the peace process and possibly the chances for any sort of resolution in the near future.

\section{Public Opinion}

Palestinian public opinion is a fundamental aspect of the peace process. Its ability to influence Palestinian leaders was especially apparent during the second Intifada, during which, “it deterred Palestinian leaders from cracking down on violence and gave political and social support and comfort to those who resorted to violence."9 The perceived effectiveness of violence and the willingness to support compromise on permanent-status issues such as borders, refugees, and Jerusalem are the focus of Palestinian public opinion (see Figure 1). ${ }^{10}$ An examination of Palestinian opinion polls suggests that the Palestinian willingness to compromise is at its highest point ever, yet they still widely accept violence against Israel. ${ }^{11}$ The collapse of the Oslo Accords and eruption of the Intifada in 2000 led the Palestinians to question the effectiveness of negotiations with Israel and turn to more violent approaches such as those 
used by Hamas. ${ }^{12}$ As Figure 1 shows, a recent decline in Palestinian public support for violence to resolve the conflict has occurred since the 2004 cease-fire, but it remains at a significant level of 38\%. Shikaki points out that “once a mutual cease-fire was instituted, Palestinian threat perception diminished and so did the level of support for violence and suicide attacks.”13 Clearly the path toward peace must be paved with mutual agreements, as opposed to unilateral actions, to stop the violence.

Sixty-eight percent of Palestinians believe that armed confrontations have succeeded in ways that negotiations could not. The recent unilateral Israeli disengagement from the Gaza Strip is one development that has fostered this belief, with $84 \%$ of the Palestinians viewing the disengagement as a victory for armed resistance. ${ }^{14}$ Despite this, the vast majority of Palestinians want peace, with $75 \%$ supporting the current ceasefire. ${ }^{15}$ No more than $36 \%$ of Palestinians living in the Gaza Strip support armed resistance and 61\% of all Palestinians in the West Bank and the Gaza Strip oppose bombing attacks or the launching of rockets from the Gaza Strip. ${ }^{16}$

Despite the clear desire for peace, only $47 \%$ of Palestinians support the collection of weapons from armed groups in the West Bank and the Gaza Strip. ${ }^{17}$ However, within the Gaza Strip, support for collection of arms from Gazan-armed groups reaches $68 \%{ }^{18}$ Instead of the collection of arms, the vast majority of Palestinians would rather see the armed groups from Hamas, Islamic Jihad, and Fatah absorbed into the Palestinian security services. ${ }^{19}$ It is not surprising that $78 \%$ of Palestinians oppose the establishment of an independent Palestinian state that would have no army; even it was protected by a strong security force. ${ }^{20}$

Although the majority of the Palestinian public supports a compromise on ending the conflict that would result in a comprehensive permanent status agreement, their willingness to actually make concessions on key issues is declining. ${ }^{21}$ While 63\% support a two-state, mutual 
recognition solution, support for final borders based on the 1967 lines, except for about 3\% of the West Bank, has dropped from $63 \%$ to $55 \%$ since $2004 .^{22}$ Palestinian support for a refugee settlement based upon UN Resolutions 194 and 242, which would allow Israel to restrict the number of refugees given Israeli citizenship, has also fallen since December 2004, from $46 \%$ to $40 \% .^{23}$

The right of return for Palestinian refugees is an especially interesting issue, because while Palestinians demand that Israel recognize the right of return for the refugees, surveys among refugees have actually found that they are not as interested in returning. Only $10 \%$ of 4,500 refugee families living in the West Bank, Gaza Strip, Jordan, and Lebanon want to live in Israel, while only $1 \%$ wanted citizenship. ${ }^{24}$ Palestinian opposition to a compromise in which East Jerusalem would become the capital of the Palestinian state with Jewish neighborhoods coming under Israel sovereignty, has increased from 54\% to 65\% since December $2004 .^{25}$

The final status of Jerusalem has been a hot button issue for decades and still contributes to the faltering of the peace process. The Palestinians are supportive of the broad concepts of peace and reconciliation, but their support declines as the issues become more specific and personal. They want peace, but on their own terms.

Overall, Palestinian public opinion is complicated by the dire economic conditions, which has caused feelings of hopelessness, anger, and desperation (see Figure 2). It is clear that Israeli policies such as the "separation wall” that further isolate and degrade the Palestinians, only encourages these feelings of anger and the desire for revenge. Palestinians often believe the Israelis are not interested in the peace process, and a lack of normal interaction with Israelis fosters this type of misperception. ${ }^{26}$ Despite this, the Palestinians have steadily become more willing to compromise and 75\% of Palestinians support the reconciliation of the two peoples 
after the establishment of a Palestinian state. ${ }^{27}$ But as far as the Palestinians are concerned, the future of the Palestinian state is uncertain. Only 52\% see the disengagement as the beginning of the end of Israeli occupation and 55\% feel that the Gaza Strip has become a big prison. ${ }^{28}$ In addition to this pessimistic attitude, only $42 \%$ expect the evacuation of most or some settlements in the West Bank, while $45 \%$ actually expect the building of more settlements. ${ }^{29}$

\section{Political Opinions}

The ideological divisions between the Palestinian parties are based on Islamic, Nationalistic, and Marxist beliefs. The Islamic position includes Hamas and the Palestinian Islamic Jihad, who ultimately want to institute Islamic law in Palestine. Fatah, the most prominent Nationalist party, has had the most control over Palestinian politics so far, but has quickly lost power to the Islamists. In addition, there have been many Palestinian Marxist groups, the most successful of which have been the Popular Front for the Liberation of Palestine, the Democratic Front for the Liberation of Palestine, and the Palestinian People's Party.

The Palestinian political parties have struggled with the dilemma of either choosing to work together and fight for the Palestinian cause, or fight against one another and gain political power. According to Mannes, Fatah began coordinating closely with the Palestinian Islamic Jihad, Hamas, the Popular Front for the Liberation of Palestine, and the Democratic Front for the Liberation of Palestine following the al-Aqsa (or Second) Intifada. ${ }^{30}$ Since then, however, local elections have become fiercely competitive and as Figure $3^{31}$ illustrates, a two-party system, dominated by Hamas and Fatah, has emerged. ${ }^{32}$

\section{Hamas}

Hamas, an acronym for Harakat al-Muqawma al-Islamiyya meaning Islamic Resistance Movement, was formed in 1987 in Gaza by Sheikh Ahmad Yassin and has played a major role in 
the recent Intifada. ${ }^{33}$ Since then, this Islamist organization has been violently committed to destroying the "Zionist entity" and replacing it with an Islamic state in all of Palestine. ${ }^{34}$ The Hamas charter is severely anti-Semitic, pulling most of its absurd claims from the notorious Protocols of the Elders of Zion. The charter not only claims that Jews have "control of the world media [and use their] wealth to stir revolutions," but also that "there was no war that broke out

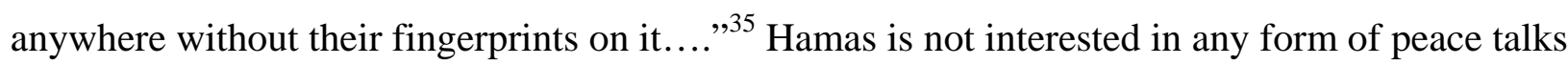
or compromises with Israel, because, as stated in their charter, "renouncing any part of Palestine means renouncing part of the religion [of Islam].”36 For Hamas, jihad is the only answer. Hamas’ clear desire to destroy Israel, along with its frequent use of suicide bombers to carry out attacks on Israeli civilians, led Israel to declare Hamas an illegal organization in September 1989. ${ }^{37}$ Since then, Hamas leaders have been the target of the Israeli Defense Forces (IDF), including the founder and spiritual leader of Hamas, Sheikh Ahmed Yassin, who was killed by the IDF on March 22, 2004. ${ }^{38}$

Hamas has been fighting for the independence of Palestine and the destruction of Israel as a militant terrorist organization and a mass social, political, and religious movement. Along with its underground Izzedine al-Qassam Brigades that carry out attacks on Israel, Hamas also operates social programs such as building schools, hospitals, and religious institutions. ${ }^{39}$ In addition to this, Hamas also holds summer camps where "children are indoctrinated in Islamist ideology and trained how to participate in violent protests." ${ }^{40}$ Furthermore, as much as $85 \%$ of Hamas’ estimated 70 million dollar budget may come from abroad and evidence suggests that Iran alone may provide as much as 10 to 20 million. ${ }^{41}$ Hamas also receives money from U.S.based organizations such as the Holy Land Foundation, which raised about 13 million for Hamas in 2000, but was closed by the FBI in the wake of $9 / 11 .{ }^{42}$ 
The deteriorating social and economic conditions in the territories have allowed Hamas to expand its influence among Palestinians within the last decade. Despite its refusal to participate in the 1996 election, Hamas, represented by the List of Change and Reform, won a landslide victory in the recent January 2006 election. $^{43}$ As the primary rival of Fatah, Hamas campaigned on domestic issues, such as political corruption and social welfare programs.

\section{Palestinian Islamic Jihad}

Fathi Shiqaqi and Abdul Aziz Odeh, two refugees from Gaza, started the Palestinian Islamic Jihad movement (PIJ), Harakat al-Jihad al-Islami al-Filastini, as a splinter group of the Palestinian Muslim Brotherhood in the mid-1980s. ${ }^{44}$ Since then, it has become a radical terrorist organization, participating in the two Intifadas and coordinating attacks with Hamas in the mid1990s. ${ }^{45}$ The PIJ also advocates an armed struggle against Israel and views any compromise with Israel as impossible. ${ }^{46}$ The radical views of the PIJ are rooted in their interpretation of the Quran, from which they have concluded, "Palestine is the focus of the religio-historical confrontation between the Muslims and their eternal enemies, the Jews."47 Because of this belief, the PIJ is committed to the liberation of Palestine, the establishment of shari'a (Islamic Law), and the elimination of Israel and pan-Islamic revival, which they believe are foreordained by God's words in the Quran. ${ }^{48}$

According to Mannes, the PIJ receives most of its financial support from Iran, which pays millions for successful attacks against Israel. ${ }^{49}$ Thankfully, the PIJ has not become a mass movement like Fatah or Hamas. However, it did gain some support after the Second Intifada in 2000, but still only has the support of $4 \%$ to $5 \%$ of the Palestinian population. ${ }^{50}$ This lack of public support is due to the PIJ's focus on its radical goals and disregard for wider political considerations. The PIJ's effectiveness and frequency of operations have also suffered since 
October 1995, when the Israeli Mossad assassinated its leader, Fathi Shqaai. ${ }^{51}$

\section{Fatah}

Fatah was established as a Palestinian nationalist movement in January 1959 by Yasser Arafat, Khaled Al-Hassan, Farouq Qaddumi, and Kalil Al-Wazzir. ${ }^{52}$ The name, Fatah, is an acronym for Harakat al-Tahrir al-Falistiniya, or the Palestinian Liberation Movement, with the

first letters in reverse order, spelling Fatah, which means conquest by Jihad. ${ }^{53}$ The Fatah constitution includes many principles that align with those of Hamas. The Israeli existence in Palestine is described as “a Zionist invasion” and Fatah envisions the Palestinian struggle as “part and parcel of the worldwide struggle against Zionism, colonialism, and international imperialism."54

Fatah’s ultimate goals are what set it apart from Hamas. These goals do include the “complete liberation of Palestine, and eradication of Zionist economic, political, military, and cultural existence,” but focus primarily on the establishment of "an independent democratic state with complete sovereignty on all Palestinian lands, and Jerusalem as its capital city,” as opposed to an Islamic state. ${ }^{55}$

Fatah does have an armed wing, the Tanzim, which has conducted an enormous variety of terror attacks in its four decades of existence. ${ }^{56}$ The Tanzim is financially supported by the Palestinian Authority and indoctrinates young Palestinians through summer camps and courses in order to prepare them to confront Israel. ${ }^{57}$

As Fatah's candidate, Abbas won an overwhelming victory in the January 2005 presidential elections. Despite this, Fatah’s public support has suffered from being associated with the corruption and incompetence of the Palestinian Authority (PA). ${ }^{58}$ Fatah has also been experiencing internal conflict between the traditional, old guard leadership and younger activists, 
such as Mohammad Dahlan and the imprisoned Marwan Barghouti. According to the AntiDefamation League, the younger members are frustrated with Fatah's corruption and the old guard's decision to exclude the younger members from key positions on the party lists. ${ }^{59}$ Indeed, this lethal combination of internal conflict and declining public support caused Fatah to lose control of the PA in the January 2006 election.

\section{Marxist Parties}

The role of socialist, Marxist parties, such as the Popular Front for the Liberation of Palestine (PFLP), the Democratic Front for the Liberation of Palestine (DFLP), and the Palestinian People's Party (PPP), in Palestinian politics has declined since the fall of the Soviet Union and the popularity of the Islamist Hamas party has increased. These groups are open to negotiations with Israel and ultimately want to establish a Palestinian state in which both Palestinians and Jews can live together. Despite their minimal power, the PFLP continues to be the second largest faction of the PLO and ran as the Martyr Abu Ali Mustafa List in the January 2006 election. ${ }^{60}$ The DFLP and PPP ran as part of joint list called al-Badeel, The Alternative, along with Palestine Democratic Union (FIDA) and independents. ${ }^{61}$ This list was led by the DFLP leader Qais Karim Khadir and ran on a platform of social issue reform. ${ }^{62}$ It received 2.8\% of the popular vote and won two of the Council's 132 seats. $^{63}$

\section{Democratization of Palestine and the Recent Elections}

The most recent Palestinian election on January 25, 2006, has once again confirmed that the Palestinians are building a fledgling democracy. Democratization of the Arab world has not proceeded quickly or easily, but the Palestinians seem to have a chance for success. ${ }^{64}$ Unfortunately, the institution of democracy in the Palestinian territories may not bode well for the peace process. Shikaki claims that if the Palestinians do manage to establish a democracy, "it 
will be one dominated by the rise of Hamas and a declining prospect for peace with Israel.”65 The Palestinians themselves are not very positive about their ability to create a democracy, with only $19 \%$ of Palestinians believing that there is a high chance that a democratic system will be established in the Palestinian Authority or a future Palestinian State. ${ }^{66}$ Despite this, the election of Mahmoud Abbas (Abu Mazen) on January 9, 2005, and the smooth shift of power thereafter, “marked the institutionalization of Palestinian democracy,” and the recent elections have strengthened this process. ${ }^{67}$

In the January 2006 elections, Palestinians elected a legislature for the first time in 10 years and expanded the legislative council from 88 seats to $132 .{ }^{68}$ These elections, which were seen as a test for democracy in the West Bank and Gaza, were a huge success, with $74.6 \%$ of the 1.3 million Palestinian voters participating. ${ }^{69}$ Although the Oslo 2 agreement signed by Israel and the Palestinian Authority in September 1995 barred candidates from running for office who "pursue the implementation of their aims by unlawful or nondemocratic means," Hamas was allowed to participate and ultimately win the majority of the seats. ${ }^{70}$ Although many had speculated that Hamas might do well prior to the elections, Hamas' landslide victory as the "List of Change and Reform," was still a shock to the international community. As shown in Figure 4, in the end, Hamas ended up receiving 74 seats, while only 45 went to Fatah. Only four other parties were able to win a few seats. ${ }^{71}$

The Hamas victory was a clear demand for change by the Palestinians, but it does not reflect the public's opinion about the peace process. While the majority of Palestinians agree with Fatah's platform at the national level, which focuses on reviving the peace process and restoring law and order, the majority of voters favored the Islamists because of local issues, such as clean government and efficient social services. ${ }^{72}$ The PA, under the control of the Fatah party, 
was seen as corrupt by $86 \%$ of Palestinians and $65 \%$ did not feel safe and secure. ${ }^{73}$ On the other hand, the Islamists who have consistently fought against the peace process have remained transparent and focused on providing social services that the Palestinians desperately need. ${ }^{74}$ Hamas promised everything that Fatah was not providing: action, strength, and transparency. Discontent with the dismal results that Fatah was able to achieve through the peace process also spurred Palestinians to vote for Hamas. One Palestinian citizen, Mr. Shaik, said, "Fatah was the majority, but they achieved nothing but the apartheid wall,” in a bitter reference to the barrier Israel has built. ${ }^{75}$ It seems that the voters ignored the fact that Hamas intends to cease all negotiations with Israel, which will cause the peace process to come to a halt. Mr. Saleh, a Palestinian living in the West Bank, said, “They [Fatah] didn’t bring us peace, but the reverse.” 76 It is clear that Israeli unilateral disengagement policies such as building a separation wall and withdrawing from Gaza without negotiations have proved to many Palestinians that Israel is not interested in working with them and that violence can pay off. ${ }^{77}$

\section{An Uncertain Future}

The results of the recent elections have placed the Israeli-Palestinian conflict on a new and uncertain path. Although the Palestinian people themselves are not an impediment to the peace process per se, Shikaki claims that the election of Hamas, an organization opposed to Palestinian-Israeli peace and a nationalist-secularist Palestinian state, threatens the future of the Palestinian state and the peace process. ${ }^{78}$ The PA will no longer be able to blame the "militants" for suicide attacks against Israeli civilians, because now the "militants" are the ruling party - the militia of Hamas. This fact will force Hamas to make some tough choices about how they will carry out their agenda. In fact, at an election rally in Gaza, Hamas leader Ismail Haniyah stated, "The constants and the strategy of Hamas do not change according to circumstances. Hamas will 
stay faithful to jihad, to resistance, to guns, to Palestine and to Jerusalem," but this sort of position will make the future very difficult for the new, Hamas-led Palestinian government. ${ }^{79}$ The Palestinians are the most foreign-aid-dependent society on earth and the United States provides about one-third of the nearly $\$ 1.1$ billion in aid that the Palestinians receive. ${ }^{80}$ Moreover, with the recent Hamas victory, the United States, Israel, and the European Union are threatening to cut off monetary aid, which could possibly cause the Hamas government to fail and force new elections to be held.

The future of the Palestinian/Israeli conflict lies partially in the hands of the radical memberships of Hamas and the Palestinian people themselves. The masses have the power to demand peace with Israel from the Hamas led government and Hamas must decide how to proceed with Israel. Although more violent means have been somewhat effective in recent years in the Palestinian perspective, the desired end has yet to be achieved. Thus, one could intuitively argue that a greater concentration on more peaceful means to bring about a resolution to the conflict would be in the Palestinian’s best interest. Furthermore, self-empowerment by the Palestinian people could bring about pressure on the Hamas-led government from within, which could make peace with Israel more likely. Perhaps such a cultural change is occurring that will allow a resolution to this age-old conflict to be found. 


\section{Bibliography}

Anti-Defamation League. “Hamas Fact Sheet.” January $2006<$ http://www.adl.org/main_israel/ hamas_facts.htm> (accessed 27 January 2006).

Anti-Defamation League. "Hamas in their own words." January 2006. <http://www.adl.org/ main_israel/hamas_own_words.htm> (accessed 27 January 2006).

Anti-Defamation League. "Parties in the Palestinian Authority Legislative Election.” $<$ http://www. adl.org/main_Israel/palestinian_parties_2006.htm> (accessed 27 January 2006).

BBC News. “Fatah: Political Heavyweight Floored.” January 2006. <http://news.bbc.co.uk/ 2/hi/in_depth/middle_east/israel_and_the_palestinians/profiles/1371998.stm> (accessed 27 January 2006).

BBC News. "Palestinian election: results in detail.” February 2006. <http://news.bbc.co.uk/1/hi/world/middle_east/4654306.stm> (accessed on 1 March 2006).

BBC News. “Who are Hamas?” January 2006. $<$ http://news.bbc.co.uk/1/hi/in_depth/middle_east/2001/israel_and_the_palestinians/profil es/1654510.stm> (accessed on 4 March 2006).

CNN News. "The Palestinian Government.” <http://www.cnn.com/SPECIALS/2003/mideast/ stories palestinian.government/index.html $>$ (accessed 28 January 2006).

Cohn-Sherbok, Dan. and Dawoud El-Alami. The Palestine-Israeli Conflict: A Beginner's Guide. Oneworld Publications: Oxford. 2002.

Cramer, Richard. How Israel Lost: The Four Questions. Simon \& Schuster: New York. 2004.

Erlanger, Steven. January 16, 2006. “Anger in the West Bank Helps Hamas Win Hearts.” The New York Times. Section A; Column 1. pg. 6.

Fateh Organization Website. Fateh Constitution. <http://www.fateh.net/e_public/ constitution.htm> (accessed on 3 March 2006).

Francis, David. "What aid cutoff to Hamas would mean.” 7 February 2006. Christian Science Monitor. http://www.csmonitor.com/2006/0227/p17s01-cogn.html (7August 2006).

Jamal, Amal. The Palestinian National Movement: Politics of Contention, 1967-2005. 2005 .Indiana University Press: Bloomington, IN.

Kaufman, Edy. and Abed, Shukri B. and Rothstein, Robert L, eds. 1993. Democracy, Peace and the Israli-Palestinian Conflict. Lynne Rienner Publishers: Boulder, CO. 
Mannes, Aaron. 2004. Profiles in Terror: The Guide to Middle East Terrorist Organizations. Towman \& Littlefield: Lanham, Maryland.

Mideast Web. Palestinian Organizations. http://www.mideastweb.org/ palestianparties.htm \#Islamic\%20Jihad (accessed on 20 January 2006).

Palestinian National Authority. Islamic Jihad Movement. http://www.pna.gov.ps/Government/ gov/Islamic_Jihad_Movement.asp (accessed on 4 February 2006).

Palestinian Center for Policy and Survey Research. December 2005. Joint Palestinian-Israeli Public Opinion Poll. http://www.pcpsr.org/survey/polls/2005/p18ejoint.html (accessed on February 7 2006).

Palestinian Center for Policy and Survey Research. March, 2005. Palestinians and Israelis Disagree on How to Proceed with the Peace Process. Poll no. 15. http://www.pcpsr.org/ survey/polls/2005/p15ejoint.html (accessed on 8 November 2005).

Palestinian Center for Policy and Survey Research. September 2005. Palestinian Public Opinion Poll No. 17. http://www.pcpsr.org/survey/polls/2005/p17a.html (accessed on 3 February 2006).

Palestinian Center for Policy and Survey Research. December 2005. Palestinian Public Opinion Poll No. 18. http://www.pcpsr.org/survey/polls/2005/p18epressrelease2.html (accessed on 3 February 2006).

Rodolph, Joseph R. Jr. ed. Encyclopedia of Modern Ethnic Conflicts. Westport, Connecticut: Greenwood Press, 2003

Shikaki, Khalil. January 2006. Willing to Compromise: Palestinian Public Opinion and the Peace Process. United States Institute of Peace Special Report \#158. http://www.usip.org/pubs/ specialreports/sr158.html (accessed on 10 February 2006). 
Figure 1. Palestinian Public Support for Violence against Israeli Civilians inside Israel

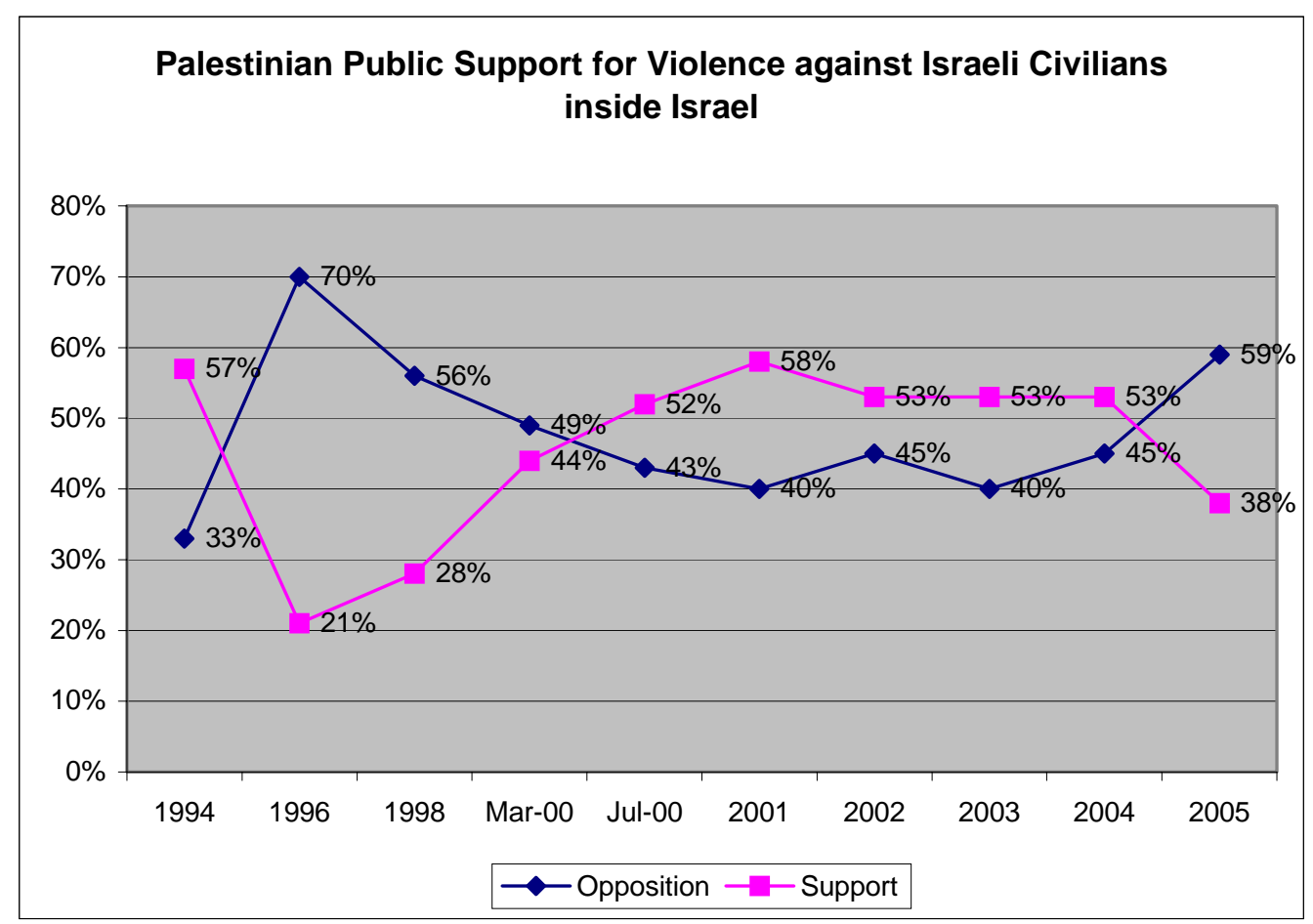


Figure 2. Summary of Palestinian Public Opinion

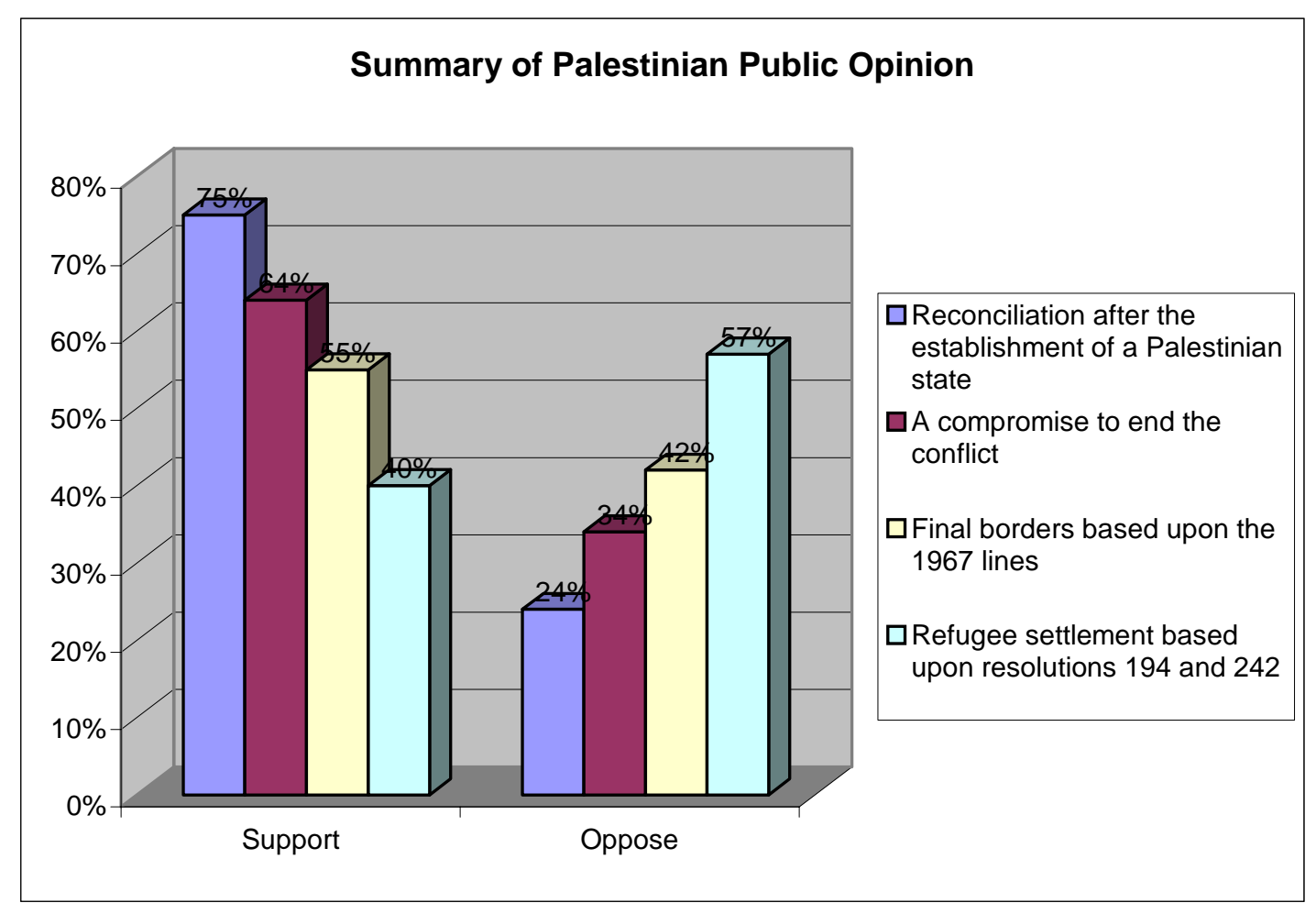


Figure 3. A Comparison of the 1996 and 2006 Election Results

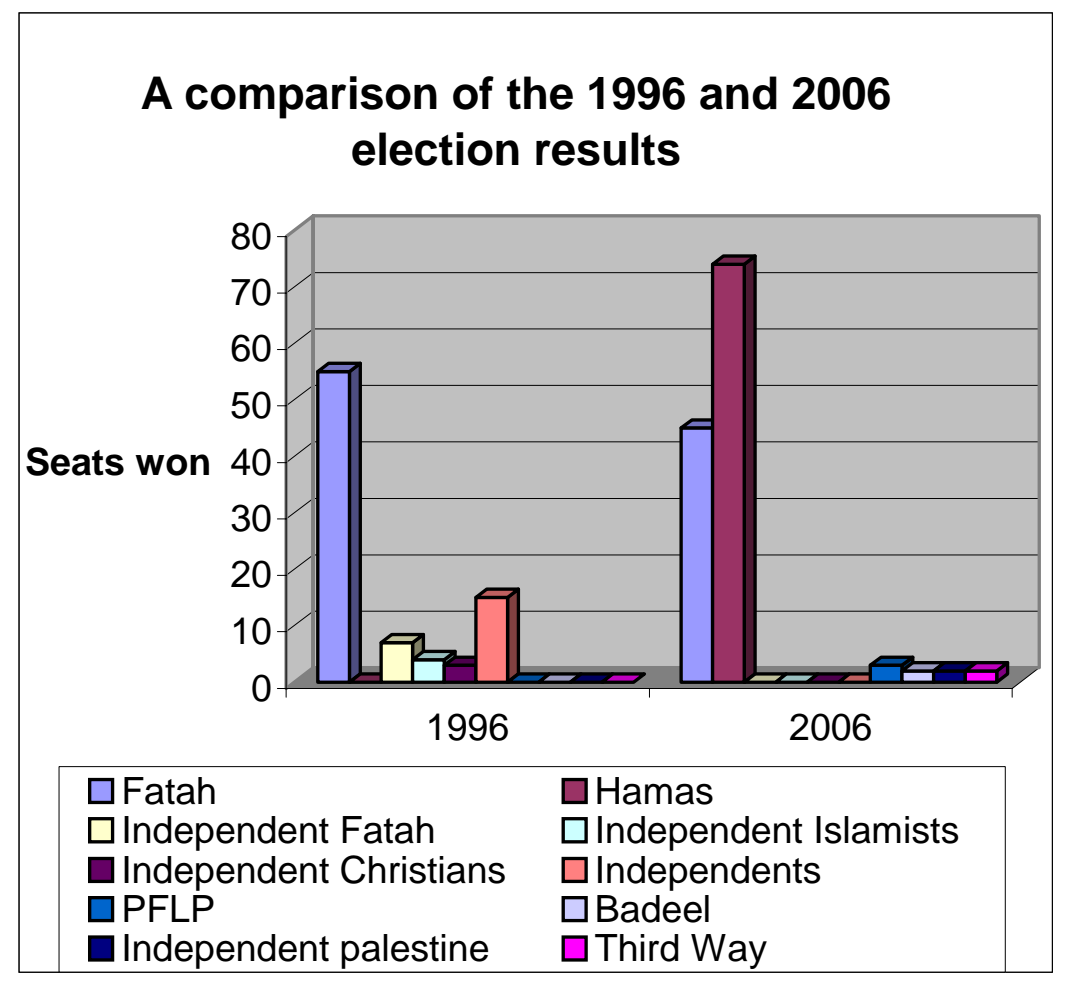


Figure 4. 2006 Election Results

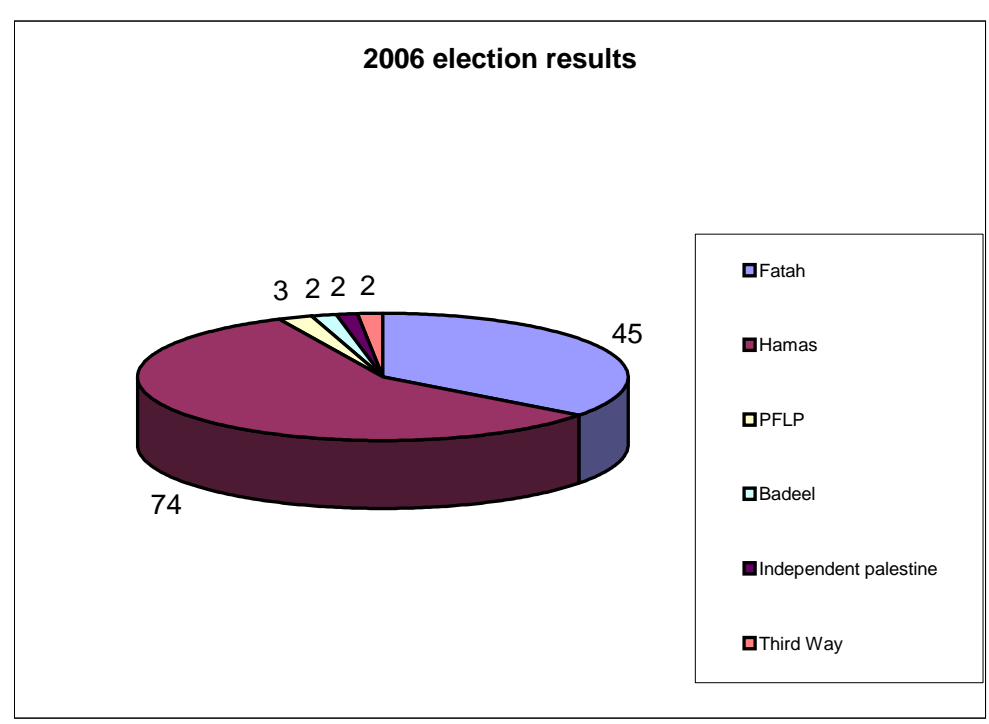




\section{Endnotes}

${ }^{1}$ Dan Cohn-Sherbok and Dawoud El-Alami, The Palestine-Israeli Conflict: A Beginner's Guide (Oxford: Oneworld Publications, 2002), 9; Joseph R. Rodolph, Jr., Encyclopedia of Modern Ethnic Conflicts (Westport CT: Greenwood Press, 2003), 162.

${ }^{2}$ Rodolph, 163.

${ }^{3}$ Rodolph, 163.

${ }^{4}$ Rodolph, 163.

${ }^{5}$ Rudolph, 163.

${ }^{6}$ Rodolph, 164.

${ }^{7}$ Rodolph, 166.

8 “The Palestinian Government," CNN News, 5 April 2001, <http://archives.cnn.com/2001/WORLD/meast/04/05/palestinian.explainer/index.html> (28 January 2006); Richard Cramer, How Israel Lost: The Four Questions (New York: Simon \& Schuster, 2004), 66-67.

${ }^{9}$ Khalil Shikaki, "Willing to Compromise: Palestinian Public Opinion and the Peace Process," United States Institute of Peace Special Report \#158, January 2006, <http://www.usip.org/pubs/ specialreports/sr158.html> (10 February 2006), pg. 12.

${ }^{10}$ Shikaki, 8.

${ }^{11}$ Shikaki, 1.

${ }^{12}$ Shikaki, 1.

13 Shikaki, 9.

14 “Palestinian Public Opinion Poll No. 17," Palestinian Center for Policy and Survey Research, September 2005, <http://www.pcpsr.org/survey/polls/2005/p17a.html> (3 February 2006).

15 "Palestinian Public Opinion Poll No. 18," Palestinian Center for Policy and Survey Research, December 2005, <http://www.pcpsr.org/survey/polls/2005/p18epressrelease2.html> (3 February 2006).

16 "Palestinian Public Opinion Poll No. 18."

17 "Palestinian Public Opinion Poll No.18."

18 "Palestinian Public Opinion Poll No. 18."

19 "Palestinian Public Opinion Poll No. 18."

20 “Joint Palestinian-Israeli Public Opinion Poll,” Palestinian Center for Policy and Survey Research, December 2005, <http://www.pcpsr.org/survey/polls/2005/p18ejoint.html> (7 February 2006).

21 Ibid.

${ }^{22}$ Ibid.; Palestinian Center for Policy and Survey Research, "Palestinian Public Opinion Poll No.18.”

${ }^{23}$ Palestinian Center for Policy and Survey Research, “Joint Palestinian-Israeli Public Opinion Poll.”

${ }^{24}$ Shikaki, pg. 11.

${ }^{25}$ Palestinian Center for Policy and Survey Research, “Joint Palestinian-Israeli Public Opinion Poll."

${ }^{26}$ Shikaki, pg. 1, 13.

${ }^{27}$ Shikaki, 7. \& Palestinian Center for Policy and Survey Research, "Palestinian Public Opinion Poll No. 17." 
${ }^{28}$ Palestinian Center for Policy and Survey Research, “Palestinian Public Opinion Poll No.18.” 29 Ibid.

${ }^{30}$ Aaron Mannes, Profiles in Terror: The Guide To Middle East Terrorist Organization. (Lanham, MD: Towman \& Littlefield, 2004), 231.

31 "Palestinian election: results in detail," BBC News, February 2006, $<$ http://news.bbc.co.uk/1/hi/world/middle_east/4654306.stm> (1 March 2006).

32 Shikaki, pg. 7.

33 Mannes, 113-115.

34 Mannes, 113.

35 "Hamas in their own words," Anti-Defamation League, January 2006,. $<$ http://www.adl.org/main_israel/hamas_own_words.htm> (27 January 2006).

36 "Hamas in their own words."

37 Mannes, 114.

38 Mannes, 122.

39 "Who are Hamas?,” BBC News, January 2006, $<$ http://news.bbc.co.uk/1/hi/in_depth/middle_east/2001/israel_and_the_palestinians/ profiles/1654510.stm> (4 March 2006).

40 Mannes, 125.

41 “Hamas Fact Sheet” Anti-Defamation League, January 2006, http://www.adl.org/main_israel/ hamas_facts.htm (27 January 2006). Mannes, 126.

${ }^{42}$ Mannes, 127.

43 "Parties in the Palestinian Authority Legislative Election,” Anti-Defamation League, $<$ http://www.adl.org/main_Israel/Palestinian_parties_2006.htm> (27 January 2006).

44 “Islamic Jihad Movement,” Palestinian National Authority,. <http://www.pna.gov.ps/Government/gov/Islamic_Jihad_Movement.asp> (4 February 2006).

${ }^{45}$ Mannes, 196-197.

${ }^{46}$ Palestinian National Authority, "Islamic Jihad Movement."

47 "Palestinian Organizations,” Mideast Web, < http://www.mideastweb.org/ palestianparties.htm \#Islamic\%20Jihad> (20 January 2006).

${ }^{48}$ Mannes, 196-197.

49 Mannes, 200.

${ }^{50}$ Mideast Web. "Palestinian Organizations.”

51 Mannes, 197.

52 Mannes, 242.

53 Mannes, 223.

54 "Fateh Constitution," Fateh Organization Website, <http://www.fateh.net/e_public/constitution.htm> (3 March 2006).

55 "Fateh Constitution."

56 Mannes, 139.

${ }^{57}$ Mannes, 234-236.

58 "Fatah: Political Heavyweight Floored,” BBC News, January 2006, $<$ http://news.bbc.co.uk/2/hi/in_depth/middle_east/ israel_and_the_palestinians/profiles/1371998.stm> (27 January 2006).

59 Anti-Defamation League. "Parties in the Palestinian Authority Legislative Election."

${ }^{60}$ Anti-Defamation League. 
${ }^{61}$ Anti-Defamation League.

${ }^{62}$ Anti-Defamation League.

${ }^{63}$ BBC News. "Palestinian election: results in detail."

${ }^{64}$ Edy. Kaufman, Shukri B. Abed, and Robert L. Rothstein. Democracy, Peace and the IsraeliPalestinian Conflict (Boulder, CO: Lynne Rienner Publishers, 1993), 46, 192.

65 Shikaki, 2.

66 "Palestinians and Israelis Disagree on how to proceed with the Peace process. Poll no. 15," Palestinian Center for Policy and Survey Research, March 2005, <http://www.pcpsr.org/ survey/polls/2005/p15ejoint.html> (8 November 2005).

${ }^{67}$ Amal Jamal, The Palestinian National Movement: Politics of Contention, 1967-2005. (Bloomington, IN: Indiana University Press, 2005), xi.

${ }^{68}$ Anti-Defamation League. "Parties in the Palestinian Authority Legislative Election."

${ }^{69}$ BBC News. "Palestinian election: results in detail."

${ }^{70}$ Anti-Defamation League. January 2006.

${ }^{71}$ BBC News. "Palestinian election: results in detail."

72 Shikaki, 4.

${ }^{73}$ Palestinian Center for Policy and Survey Research, "Palestinian Public Opinion Poll No.18.”

74 Shikaki, 7.

75 Steven Erlanger. “Anger in the West Bank Helps Hamas Win Hearts,” The New York Times, 16 January 2006, sec. 1A, p. 6.

${ }^{76}$ Erlanger, 6.

${ }^{77}$ Shikaki, 5.

${ }^{78}$ Shikaki, 4.

${ }^{79}$ Ismail Haniyah, Hamas leader, at an election rally in Gaza, January 20, 2006, Gulf Daily News, Bahrain. \& Anti-Defamation league, <http://www.adl.org/ main_israel/hamas_own_words.htm $>$ (27 January 2006).

${ }^{80}$ David Francis, “What aid cutoff to Hamas would mean” Christian Science Monitor, February 2006. http://www.csmonitor.com/2006/0227/p17s01-cogn.html (7August 2006). 